\title{
Discrimination Due to Sexual Orientation and Associated Factors Among Men Who have Sex with Men in 12 Brazilian Cities: A Respondent-Driven Sampling Survey
}

Laio Magno ( $\sim$ laiomagnoss@gmail.com )

Universidade do Estado da Bahia https://orcid.org/0000-0003-3752-0782

Inês Dourado

Universidade Federal da Bahia

Andrea Fachel Leal

UFRGS: Universidade Federal do Rio Grande do Sul

Daniela Knauth

UFRGS: Universidade Federal do Rio Grande do Sul

Mark Drew Crosland Guimarães

UFMG: Universidade Federal de Minas Gerais

Ximena Pamela Díaz Bermúdez

Universidade de Brasilia

Gustavo Machado Rocha

UFMG: Universidade Federal de Minas Gerais

Maria Amélia Veras

Faculdade de Ciências Médicas da Santa Casa de São Paulo: Faculdade de Ciencias Medicas da Santa Casa de Sao Paulo

Carl Kendall

Tulane University School of Medicine

Ana Maria de Brito

Centro de Pesquisas Aggeu Magalhães: Centro de Pesquisas Aggeu Magalhaes

Lígia Kerr

UFC: Universidade Federal do Ceara

Research article

Keywords: Sexual and Gender Minorities, Men who have sex with men, Social Discrimination, Latent Class Analysis, Brazil

Posted Date: December 1st, 2020

DOI: https://doi.org/10.21203/rs.3.rs-115164/v1 
License: () (1) This work is licensed under a Creative Commons Attribution 4.0 International License. Read Full License 


\section{Abstract}

\section{Background}

Discrimination due to sexual orientation (DDSO) has an important association with health outcomes among men who have sex with men (MSM). This study aimed to analyse factors associated with DDSO among MSM in 12 Brazilian cities.

\section{Methods}

A cross-sectional study with 4,176 MSM participants recruited in 2016 through respondent-driven sampling in 12 Brazilian cities. In this analysis, ordinal logistic regression was used to assess associations with previously identified levels of DDSO, which were based on latent class analysis (LCA) on 13 variables from the discrimination section of the questionnaire. Weighted odds ratios and their respective $95 \%$ confidence interval were estimated using Gile estimator.

\section{Results}

Most participants were young, single, had a religious affiliation, a post-primary education, were black or mixed race and had a high and average socio-economic status. More than half reported DDSO in the previous 12 months (65\%). DDSO was then classified into four latent classes (very high, high, average or low). We observed an independent association among the four latent classes of DDSO and the following variables: age $<25$ years old, white skin color, experience of sexual or physical violence, revealing to a father his sexual orientation as MSM, experienced suicidal ideation in the previous two weeks and had taken illicit drugs in the last six months.

\section{Conclusion}

We observed that sociodemographic characteristics, previous violence experiences, family knowledge about sexual orientation and mental health issues were associated with DDSO. Monitoring DDSO throws into sharp relief our broad social, political, and moral failings. These results should be used for the purposes of surveillance and protection for the human rights.

\section{Introduction}

Men who have sex with men (MSM) suffer discrimination due to sexual orientation (DDSO), defined as the manifestation of heteronormativity and homophobia against MSM [1]. DDSO plays an important role in maintaining a high prevalence of HIV infections among MSM in several countries [1-3]. Studies conducted with MSM also demonstrate the greater likelihood of illnesses and risk behaviors among those who suffer DDSO, such as anal sex without a condom [4], experiences of violence [5, 6], mental distress [4,7-10] and abusive use of alcohol and other drugs $[4,8,11,12]$. Furthermore, DDSO is one of the main barriers MSM faces when accessing health services [13-18].

There has been an alarming increase in DDSO. In the last decade, studies show high proportion of DDSO among MSM in different countries [19] including Brazil [10, 20-22]. Sexual and affective practices among MSM remain illegal in 70 United Nations member states and are punishable by the death penalty in six countries (three in Asia: Iran, Saudi Arabia and Yemen; and three in Africa: Nigeria, Sudan and Somalia) and is a possibility in another five 
countries (Mauritania, the United Arab Emirates, Qatar, Pakistan and Afghanistan) [19]. In Latin America, homosexuality is not illegal, nevertheless, the patriarchal, religious and sexist context of countries in this region adds to the impact of DDSO on the physical, mental, social and cultural well-being of MSM [23-25].

Brazil's judicial system has protective human rights measures for MSM, including recognizing same sex marriage in 2011 [26], and categorizing discrimination against LGBT individuals as racism, a prosecutable offense, until such time as the Brazilian National Congress approves specific legislation related to this issue [27]. Despite this, in 2018, 420 LGBT individuals were murdered, targeted for their identities, of which 191 (45\%) were MSM [28]. In 2009 and 2016, cross-sectional studies of MSM recorded an increase in the prevalence of self-reported DDSO from 27.7-65\% [21, 29]. In 2009, the likelihood of reporting DDSOs was higher among younger MSM (below 30 years), with more schooling, a history of sexual or physical violence, suicidal ideation, unprotected receptive anal sex and among those who participated in support organizations (such as an NGO) [29].

This study aims at identifying factors associated with DDSO among MSM in Brazil.

\section{Materials And Methods}

\section{Study design and location}

This study utilizes data from the behavioural and biological surveillance survey entitled "The 12 city HIV surveillance survey among MSM in Brazil 2016 using respondent-driven sampling (RDS)” [30] (\#914BRZ1138, BRAZIL, AIDS-SUS) conducted in 2016 in 12 Brazilian cities from all five regions in Brazil: Manaus and Belém in the North; Fortaleza, Recife and Salvador in the Northeast; Brasília and Campo Grande in the Central-West; Belo Horizonte, Rio de Janeiro and São Paulo in the Southeast; and Curitiba and Porto Alegre in the Southern region. Cities were defined, a priori, by the Department of Chronic Conditions and Sexually Transmitted Infections of the Ministry of Health (DCST /MoH).

\section{Participants}

The survey sample consisted of 4,176 MSM who reported at least one sexual experience in the 12 months prior to the study; were 18 years of age or older; did not identify as transsexual or transgender women; resided, studied or worked in the selected cities; and signed an Informed Consent Form. To recruit participants, we used RespondentDriven Sampling (RDS) as recommended for hard-to-reach populations [31]. Formative research using semistructured interviews and focus groups was conducted in each city to prepare for the main study. Six MSM were selected purposively to serve as "seeds". These were individuals of different ages and socio-economic status with relatively large social contact networks. Each of these seeds was asked to recruit three other MSM from their social network by offering a voucher to each recruit. These vouchers provided information about the site and also contained a number linking the recruiter and the recruit. This procedure was repeated with each eligible participant until the desired sample size was reached. Participants received a primary and secondary incentive of BRL 25.00 (US\$ 7.40) for each of their recruits to reimburse expenses such as transport and food.

\section{Data collection}

Data was collected through computer assisted personal interview (CAPI) in the study office in each city, where blood samples were drawn for HIV and syphilis testing. Upon completion of the interviews, these were immediately sent via internet to a central server. The research project was approved by the Research Ethics 
Committee of the Federal University of Ceará. Further details about the methodology may be found in Kendall [30].

\section{Study variables}

The outcome variable, DDSO, was defined by Latent Class Analysis (LCA) and it was based on thirty questions divided in four DDSO dimensions: i) discrimination in the work sphere (i.e. not selected for a job or fired from a job); ii) educational setting (i.e. mistreated or marginalized by teachers and classmates at school/college); iii) private domain (i.e. excluded or marginalized from groups of friends, neighbors, family, or religious environment); iv) and the public sphere (i.e. blackmailed or extorted money, poorly cared for in health services, prevented from donating blood, mistreated in public services, mistreated by police officers and prevented from entering in a market) as previously described [21]. LCA is a useful method for identifying underlying groups of individuals with similar profiles [32].

The independent (explanatory) variables included in this analysis were: a) sociodemographics: age ( $<25$ years and $\geq 25$ years), self-reported race/skin color (white, black and mixed race - pardo), education (primary or incomplete secondary, post-secondary education), religious affiliation (yes, no) and marital status (single or separated or widowed and married or living together or civil union); b) economic: three economic groups were created: A-B: high income; C: average income: and D-E: low income, based on the Brazilian Economic Classification Criteria [33]; c) self-reported sexual identity (heterosexual and gay); d) ever experience violence due to sexual orientation (lifetime): sexual (yes, no) or physical (yes, no); e) fear of visiting public places (yes, no); f) family approval of sexual orientation (approves; disapproves/indifferent; and family does not know); g) disclosure of sexual orientation: told friends (yes, no), told mother (yes, no), told father (yes, no); h) participation in LGBT NGOs (yes, no); i) ever tested for HIV (lifetime) (yes, no); j) suicidal ideation in the previous two weeks (yes, no); l) alcohol use classified by audit score ( low risk and abstemious; risk and high risk; and dependent) and illicit drug use in the previous 6 months (yes, no).

\section{Data analysis}

Gile successive sampling estimator [34] was used to calculate the weighted ratio estimators using RDS Analyst [35]. Data from the 12 cities were merged into a single database in which each city was treated as its own strata. The previously defined latent variable DDSO [21] and the RDS weights were transferred to the current database for descriptive, bivariate, and multivariate analyses. Stata 15.0 was used with complex survey data analysis tools (Stata Corp, College Station, TX, USA, 2019).

Multivariate analysis included ordinal logistic regression modelling, as the outcome variable was ordinal. And estimators were adjusted with the simultaneous generation of a constant association measure across the categories of the outcome variable [36].

The construction of the logistic model's weighted odds ratio began with a bivariate analysis to assess the factors associated with the outcome variable. Variables associated with DDSO in the bivariate analysis at a p-value of 0.20 were included in the multivariate analysis. Only those with $p$-value $<0.05$ remained in the final model. $A$ review of the literature regarding factors associated with DDSO was also important for the selection of these factors. Weighted odds ratios (OR) with $95 \%$ confidence intervals $(95 \% \mathrm{Cl})$ were used as measures of association between explanatory factors and DDSO. 


\section{Results}

We recruited 4,176 MSM in the 12 Brazilian cities. Most of these MSM were young, $56.1 \%$ under 25 years old; $86.3 \%$ were single and $53.1 \%$ named a religious affiliation; $70.3 \%$ reported post-primary education; $41.8 \%$ of mixed race (Pardo), 31.5\% whites and 22.7\% blacks. $42.4 \%$ percent of MSM reported high income level (A-B), another $41.7 \%$ reported average income (C) and $15.9 \%$ low income (D-E). The vast majority of participants (92.4\%) reported gay sexual orientation (Table 1 ). 
Table 1

Characteristics of the population of men who have sex with men in 12 Brazilian cities, 2016

\begin{tabular}{|c|c|c|c|c|}
\hline \multirow[t]{2}{*}{ Variables } & \multirow[t]{2}{*}{$\mathrm{n} / \mathrm{N}^{\mathrm{a}}$} & \multirow[t]{2}{*}{$\% \mathrm{~b}$} & \multicolumn{2}{|c|}{$95 \% \mathrm{Cl}^{\mathrm{c}}$} \\
\hline & & & LL & $\mathrm{HL}$ \\
\hline \multicolumn{5}{|l|}{ Age } \\
\hline$<25$ years & $2,503 / 4,129$ & 56.1 & 52.4 & 59.7 \\
\hline$\geq 25$ years & $1,626 / 4,129$ & 43.9 & 40.3 & 47.6 \\
\hline \multicolumn{5}{|l|}{ Race/skin color } \\
\hline White & $1,285 / 4,106$ & 31.5 & 28.2 & 35.0 \\
\hline Black & $903 / 4,106$ & 22.7 & 19.7 & 26.1 \\
\hline Mixed race (pardo) & $1,768 / 4,106$ & 41.8 & 38.3 & 45.3 \\
\hline Indigenous & $64 / 4,106$ & 1.9 & 1.0 & 3.3 \\
\hline Asian origin & $86 / 4,106$ & 2.2 & 1.5 & 3.3 \\
\hline \multicolumn{5}{|l|}{ Education } \\
\hline Primary or incomplete secondary & $3,115 / 4,132$ & 70.3 & 67.1 & 73.3 \\
\hline Post-secondary education & $1,017 / 4,132$ & 29.7 & 26.8 & 32.9 \\
\hline \multicolumn{5}{|l|}{ Religious affiliation } \\
\hline Yes & $2,176 / 4,096$ & 53.1 & 49.5 & 56.7 \\
\hline No & $1,920 / 4,096$ & 46.9 & 43.3 & 50.6 \\
\hline \multicolumn{5}{|l|}{ Marital status } \\
\hline Single/separated/widowed & $3,578 / 4,115$ & 86.3 & 83.6 & 88.6 \\
\hline Married or living together & $537 / 4,115$ & 13.7 & 11.4 & 16.4 \\
\hline
\end{tabular}

${ }^{\text {a }}$ Crude estimate

b Estimate weighted by Gile-SS.

${ }^{c}$ Cl: confidence interval; LL: [lower limit]; HL: [higher limit]. 


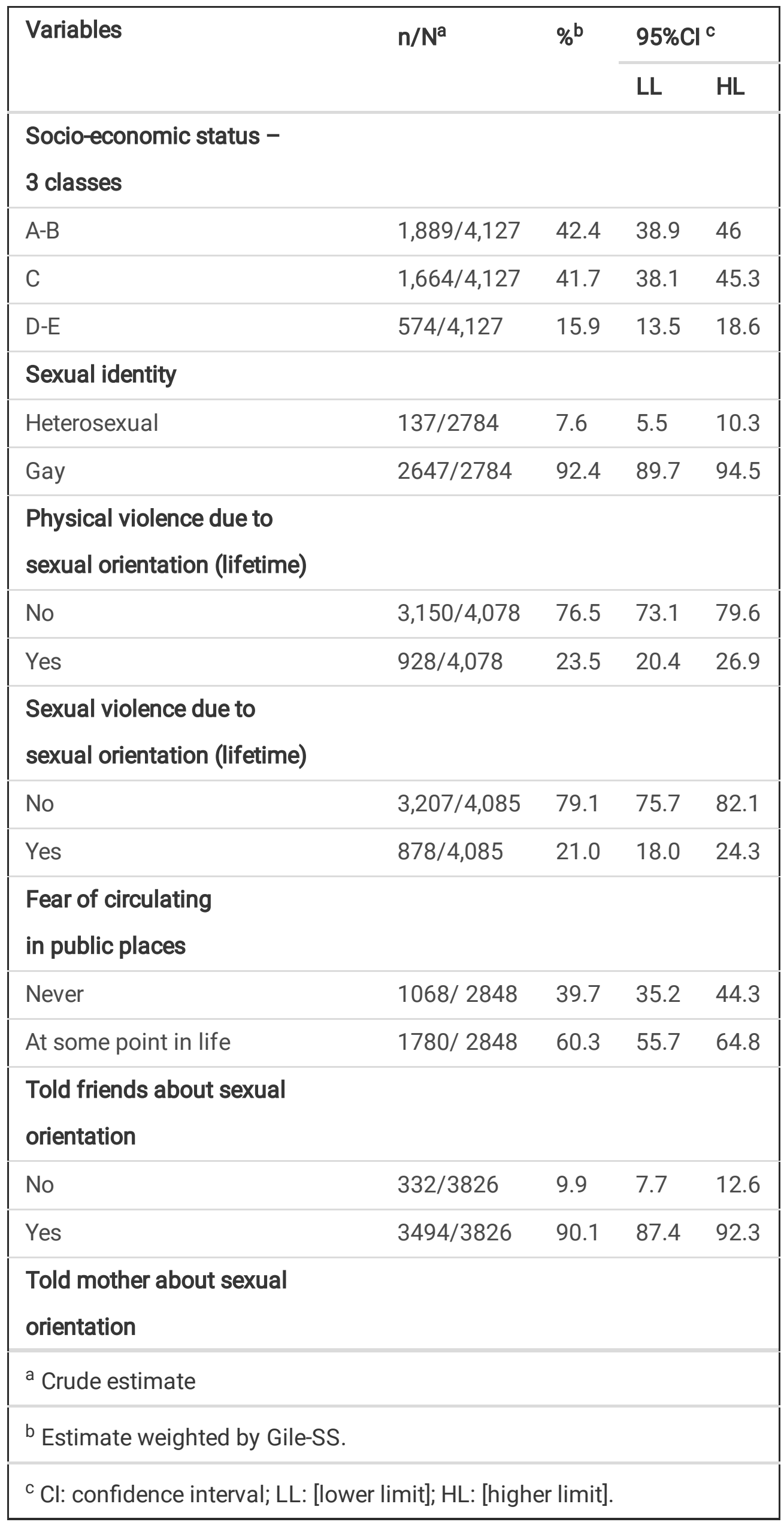




\begin{tabular}{|c|c|c|c|c|}
\hline \multirow[t]{2}{*}{ Variables } & \multirow[t]{2}{*}{$\mathrm{n} / \mathrm{N}^{\mathrm{a}}$} & \multirow[t]{2}{*}{$\%$} & \multicolumn{2}{|c|}{$95 \% \mathrm{Cl}^{\mathrm{C}}$} \\
\hline & & & LL & $\mathrm{HL}$ \\
\hline No & $1345 / 3826$ & 37.2 & 33.7 & 40.9 \\
\hline Yes & $2481 / 3826$ & 62.8 & 59.1 & 66.3 \\
\hline \multicolumn{5}{|l|}{$\begin{array}{l}\text { Told father about sexual } \\
\text { orientation }\end{array}$} \\
\hline No & $2170 / 3826$ & 57.0 & 53.2 & 60.8 \\
\hline Yes & $1656 / 3826$ & 43.0 & 39.2 & 46.8 \\
\hline \multicolumn{5}{|l|}{$\begin{array}{l}\text { Family approval of } \\
\text { sexual orientation }\end{array}$} \\
\hline Approves & $1975 / 4037$ & 45.4 & 41.7 & 49.1 \\
\hline Disapproves/Indifferent & $1391 / 4037$ & 33.4 & 30.2 & 36.7 \\
\hline Family does not know & $671 / 4037$ & 21.3 & 18.3 & 24.6 \\
\hline \multicolumn{5}{|l|}{$\begin{array}{l}\text { Participates in an } \\
\text { LGBT/NGO }\end{array}$} \\
\hline No & $3335 / 4076$ & 82.1 & 79.2 & 84.7 \\
\hline Yes & $741 / 4076$ & 17.9 & 15.3 & 20.8 \\
\hline \multicolumn{5}{|c|}{ Ever tested for HIV (lifetime) } \\
\hline No & $1226 / 4122$ & 33.8 & 30.5 & 37.2 \\
\hline Yes & $2896 / 4122$ & 66.2 & 62.8 & 69.6 \\
\hline $\begin{array}{l}\text { Suicidal ideation } \\
\text { in previous } 2 \text { weeks }\end{array}$ & & & & \\
\hline
\end{tabular}

${ }^{\text {a }}$ Crude estimate

${ }^{\mathrm{b}}$ Estimate weighted by Gile-SS.

${ }^{c} \mathrm{Cl}$ : confidence interval; LL: [lower limit]; HL: [higher limit]. 


\begin{tabular}{|lllll|}
\hline Variables & \multirow{2}{*}{$\mathrm{n}^{\mathrm{a}}$} & \multirow{2}{*}{$\mathrm{N}^{\mathrm{b}}$} & \multicolumn{2}{c|}{$95 \% \mathrm{Cl}^{\mathrm{c}}$} \\
\cline { 3 - 5 } & & & $\mathrm{LL}$ & $\mathrm{HL}$ \\
\hline No & $3358 / 4119$ & 82.0 & 79.2 & 84.4 \\
\hline Yes & $761 / 4119$ & 18.0 & 15.6 & 20.8 \\
\hline Alcohol use & & & & \\
\hline Low risk/abstemious & $2047 / 3938$ & 54.6 & 51.0 & 58.2 \\
\hline Risky/High risk & $1541 / 3938$ & 35.7 & 32.4 & 39.2 \\
\hline Dependent & $350 / 3938$ & 9.7 & 7.8 & 11.9 \\
\hline $\begin{array}{l}\text { Illicit drug uses } \\
\text { in previous 6 months }\end{array}$ & & & & \\
\hline No & & & & \\
\hline Yes & $2055 / 4062$ & 51.6 & 48.0 & 55.3 \\
\hline a Crude estimate & $2007 / 4062$ & 48.4 & 44.7 & 52.0 \\
\hline b Estimate weighted by Gile-SS. & & & & \\
\hline c Cl: confidence interval; LL: [lower limit]; HL: [higher limit]. & \\
\hline
\end{tabular}

The majority also reported fear of visiting public spaces (60.3\%), while about a quarter of the participants had experienced physical (23.5\%) or sexual (21.0\%) violence. Regarding disclosure of sexual orientation, most disclosed to their friends $(90.1 \%)$ and their mothers $(62.8 \%)$, while fewer disclosed to their fathers $(43.0 \%) .45 .4 \%$ reported family approval of their sexual orientation; $33.4 \%$ reported family disapproval or indifference to their sexual orientation, and $21.3 \%$ reported that the family did were unaware of their sexual orientation. A small percentage $(17.9 \%)$ reported participating in an LGBT NGOs. A third (33.8\%) had never taken an HIV test and almost a fifth (18.0\%) experienced suicidal ideation in the previous two weeks of the survey. In terms of alcohol use, $35.7 \%$ were classified as risk or high risk, and $9.7 \%$ as dependent; and almost half of the participants reported having illicit drug use in the past 6 months before the survey (48.4\%) (Table 1).

Among those who reported any DDSO (65.0\%), a high proportion of MSM (73.1\%) did not shared this situation with anyone. Of those who did, $19.7 \%$ shared with their family, $6.1 \%$ with their partners/spouses, $0.9 \%$ with friends, $0.1 \%$ with health professionals and another $0.1 \%$ with the police (Table 2 ). 
Table 2

Self-reported discrimination due to sexual orientation among MSM in 12 Brazilian cities, 2016.

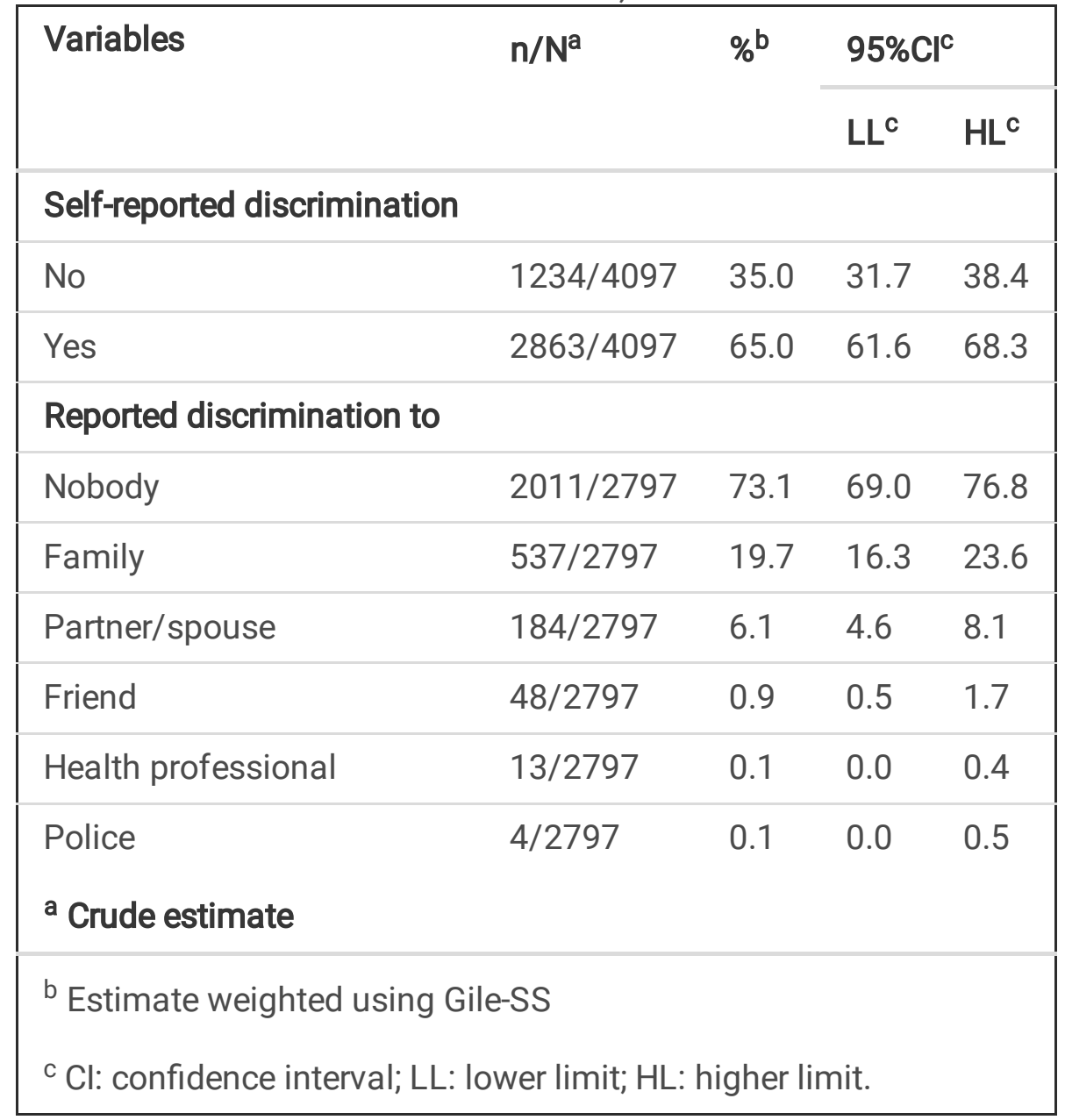

Table 3 shows the association between explanatory variables and the DDSO categories. Bivariate analysis indicated an increasing odds of DDSO among MSM under 25 years old, of mixed race (pardo) and white, who had post-secondary education, and with higher socio-economic status. In addition, gay sexual identity, sexual and physical violence, family disapproval or indifferent, told mother and father about sexual orientation, and participating in an LGBT NGO were also associated. Finally, a HIV test in lifetime, suicidal ideation experience, risk or high risk of alcohol use and illicit drug use in the previous six months showed increased odds of DDSO. In the final multivariate analysis, the following variables were independently associated with DDSO: age under 25 years old, white skin color, experience of sexual and physical violence, shared sexual orientation to their father, experienced suicidal ideation in the previous two weeks and used illicit drugs in the previous six months (Table 3). 
Table 3

Bivariate and multivariate analysis of the association between DDSO and predictor variables.

\begin{tabular}{|c|c|c|c|c|c|c|c|}
\hline Variables & DDSO $^{a}$ & & & & & Bivariate $^{a}$ & Multivariate $^{\mathrm{a}}$ \\
\hline & $\begin{array}{l}\text { Low \% } \\
(n=1,890 ; \\
46.19 \% \text {; })\end{array}$ & $\begin{array}{l}\text { Average } \\
\% \\
(n=1,437 ; \\
\left.35.1 \%^{b}\right)\end{array}$ & $\begin{array}{l}\text { High } \\
\% \\
(n=673 ; \\
16.4 \%)\end{array}$ & $\begin{array}{l}\text { Very } \\
\text { high\% } \\
\text { (n=92; } \\
\left.2.2 \%^{b}\right)\end{array}$ & $\begin{array}{l}\mathrm{p} \\
\text { value }\end{array}$ & $\begin{array}{l}\mathrm{OR}(95 \% \\
\mathrm{Cl})\end{array}$ & OR $(95 \% \mathrm{Cl})$ \\
\hline Age & & & & & 0.00 & & \\
\hline$>=25$ years & 64.3 & 24.8 & 9.7 & 1.2 & & 1 & 1 \\
\hline$<25$ years & 44.9 & 36.6 & 17.0 & 1.5 & & $\begin{array}{l}2.13 \\
(1.60- \\
2.83)\end{array}$ & $\begin{array}{l}1.66(1.21- \\
2.27)\end{array}$ \\
\hline Race/skin color & & & & & 0.04 & & \\
\hline Black & 58.5 & 30.0 & 9.9 & 1.6 & & 1 & 1 \\
\hline Mixed race (Pardo) & 52.7 & 31.2 & 14.9 & 1.2 & & $\begin{array}{l}1.29 \\
(0.92- \\
1.82)\end{array}$ & $\begin{array}{l}1.38(0.98- \\
1.96)\end{array}$ \\
\hline White & 48.4 & 31.4 & 18.9 & 1.3 & & $\begin{array}{l}1.58 \\
(1.13- \\
2.21)\end{array}$ & $\begin{array}{l}1.43(1.02- \\
2.01)\end{array}$ \\
\hline Education & & & & & 0.00 & & \\
\hline $\begin{array}{l}\text { Primary or incomplete } \\
\text { secondary }\end{array}$ & 66.4 & 21.1 & 10.8 & 1.7 & & 1 & \\
\hline $\begin{array}{l}\text { Post-secondary } \\
\text { education }\end{array}$ & 47.6 & 35.9 & 15.3 & 1.2 & & $\begin{array}{l}2.00 \\
(1.42- \\
2.83)\end{array}$ & \\
\hline Religious affiliation & & & & & 0.25 & & \\
\hline No & 50.7 & 31.9 & 15.7 & 1.7 & & 1 & \\
\hline Yes & 56.2 & 30.6 & 12.2 & 1.1 & & $\begin{array}{l}0.78 \\
(0.59- \\
1.03)\end{array}$ & \\
\hline Marital status & & & & & 0.14 & & \\
\hline Single & 54.2 & 31.0 & 13.8 & 1.0 & & 1 & \\
\hline $\begin{array}{l}\text { Married/together/ civil } \\
\text { union }\end{array}$ & 48.5 & 33.8 & 14.1 & 3.6 & & $\begin{array}{l}1.27 \\
(0.83- \\
1.92)\end{array}$ & \\
\hline Socio-economic level & & & & & 0.00 & & \\
\hline D-E & 67.9 & 21.4 & 9.1 & 1.5 & & 1 & \\
\hline c & 56.0 & 28.0 & 15.0 & 1.1 & & $\begin{array}{l}1.67 \\
(1.06-\end{array}$ & \\
\hline
\end{tabular}




$\begin{array}{llllll}\text { A-B } & 45.0 & 38.8 & 14.5 & 1.7 & 2.35 \\ & & & & & (1.52- \\ & & & & & 3.63)\end{array}$

\section{Sexual Identity}

$\begin{array}{lllllll}\text { Hetero } & 80.2 & 17.8 & 1.6 & 0.4 & 0.00 & 1 \\ \text { Gay } & 44.9 & 36.1 & 17.4 & 1.6 & & \begin{array}{l}5.15 \\ (2.30- \\ \end{array} \\ & & & & & & 11.50)\end{array}$

Sexual violence due

0.00

sexual orientation

(lifetime)

$\begin{array}{lllllll}\text { No } & 59.0 & 30.6 & 9.6 & 0.9 & 1 & 1 \\ \text { Yes } & 33.1 & 33.6 & 30.3 & 3.0 & \begin{array}{l}3.37 \\ (2.29-\end{array} & \begin{array}{l}2.33(1.58- \\ \end{array} \\ & & & & & 4.95) & \end{array}$

0.00

Physical violence due

to

sexual orientation

(lifetime)

$\begin{array}{lllllll}\text { No } & 61.3 & 29.2 & 8.9 & 0.6 & 1 & 1 \\ \text { Yes } & 28.5 & 38.3 & 29.4 & 3.7 & \begin{array}{l}4.26 \\ (3.00-\end{array} & \begin{array}{l}3.08(2.11- \\ \end{array} \\ & & & & & 6.06) & \end{array}$

Family approval

0.00

of sexual orientation

$\begin{array}{llllll}\text { Approves } & 49.8 & 34.1 & 14.5 & 1.6 & 1 \\ \text { Disapproves/Indifferent } & 42.0 & 36.9 & 19.8 & 1.4 & 1.37 \\ & & & & & (1.01- \\ & & & & & 1.85) \\ \text { Family doesn't know } & 77.4 & 18.3 & 3.6 & 0.7 & \begin{array}{l}0.28 \\ (0.18-\end{array} \\ & & & & & 0.43)\end{array}$

Told mother

0.00

about sexual

orientation

$\begin{array}{llllll}\text { No } & 61.5 & 25.9 & 11.4 & 1.2 & 1 \\ \text { Yes } & 42.1 & 39.5 & 17.1 & 1.4 & 2.04 \\ & & & & & (1.52-\end{array}$




\section{Told father}

about sexual

orientation

$\begin{array}{lllllll}\text { No } & 57.7 & 29.2 & 11.9 & 1.2 & 1 & 1 \\ \text { Yes } & 38.2 & 41.4 & 18.9 & 1.5 & 2.05 & 2.00(1.47- \\ & & & & & 2.72) & 2.72)\end{array}$

Participates

0.00

in an LGBT/NGO

$\begin{array}{llllll}\text { No } & 55.9 & 31.3 & 11.8 & 1.0 & 1 \\ \text { Yes } & 41.9 & 32.3 & 22.9 & 2.9 & 1.94 \\ & & & & & (1.33- \\ & & & & & 2.83)\end{array}$

\section{Ever tested for HIV}

(lifetime)

$\begin{array}{llllll}\text { No } & 62.7 & 24.5 & 11.6 & 1.2 & 1 \\ \text { Yes } & 48.7 & 34.8 & 15.0 & 1.5 & 1.67 \\ & & & & & (1.22- \\ & & & & & 2.29)\end{array}$

Suicidal ideation

in previous 2 weeks

$\begin{array}{lllllll}\text { No } & 56.5 & 31.4 & 11.4 & 0.8 & 1 & 1 \\ \text { Yes } & 37.9 & 32.5 & 25.3 & 4.3 & \begin{array}{l}2.45 \\ (1.708-\end{array} & 2.09(1.46- \\ & & & & & 3.52) & \end{array}$

\section{Alcohol use}

Low risk/abstemious

Risk/High risk

Dependent

62.5

54.7

31.5

46.4

36.6

13.0

0.8

1.7

0.05

0.00

\subsection{0}

(1.22-

2.29) 
a Estimate weighted by Gile-SS;

${ }^{\mathrm{b}}$ Crude estimate;

\section{Discussion}

This study identified a high proportion of DDSO among MSM in Brazil in 2016 (65.0\%), which is more than twice compared to data in a similar study in 2009 (an RDS study conducted with MSM in 10 Brazilian cities) (27.7\%) [29]. Younger men in our study were more likely to report DDSO compared to older men, a trend already observed in 2009 [29] and in other countries [37, 38]. Over the past decades, in some countries, there has been a growing tolerance for sexual minorities that might lead to more openness and thus opportunity to become a target of discrimination. In contexts of less tolerance, MSM may adopt masking behaviors. Another explanation may be the rising homophobia engendered by the current and previous government in Brazil, who have implicitly and explicitly granted permission for the expression of homophobia. A third hypothesis is that there could be a desensitization arising from repeated exposure to abuse among older MSM, and the creation of cognitive mechanisms that may partially neutralize the identification and effects of discrimination [39]. Part of this desensitization may explain lower reports of experiences of DDSO.

White MSM were more likely to experience DDSO than black men. In Brazil, higher educational levels are found among white men compared to black men [40] and we may hypothesize that the higher education might be associated to the greater perception of discrimination and to more willingness to report [41]. Stigma and discrimination are consequences of social structures and forms of domination used in society to identify and discriminate against all divergence from normative white male identity. In Brazil, the DDSO affects even white and educated men when they express or identify their sexual orientation. On the other hand, for black MSM, DDSO presents in an intersectional manner alongside racial and perhaps class discrimination that could be multiplying health outcome effects [42-44].

Other concern relates to the fact that only $26.9 \%$ of MSM shared or reported DDSO. Moreover, when they did so, the vast majority did not report to the judicial system, but rather to their friends or relatives. This lack of reporting is problematic in two senses. Firstly, because of underreporting, it underestimates DDSO in Brazilian society, reducing visibility of this problem to public administrators, civil society and legislators. On the other hand, this may affect the physical and mental health of MSM, since not talking about the problem may aggravate internalized homophobia $[45,46]$, which can be defined as self-directed homophobic attitudes that in turn can lead to low self-esteem and self-hatred [47]. This difficulty in reporting discrimination may be aggravated if there is a lack of family acceptance. In this study, we demonstrated that one-third of participants reported that their families do not approve of their sexual identity and disclosing identity to a father was independently associated with greater likelihood of DDSO.

In this study, both physical and sexual violence were strongly associated with DDSO, as in other studies [6, 29]. Discrimination and violence may influence perception of insecurity among MSM: $60 \%$ reported feeling fear of circulating in public places, a much higher percentage than found in hostile venues for MSM in Abuja city, Nigeria $(17.0 \%)[48]$.

Our study also demonstrated an association with suicidal ideation in the previous two weeks and illicit drug use in the previous six months before the survey, respectively. We note the time-frame differences as DDSO was 
analysed over the previous 12 months. Despite this, other studies showed an association between DDSO and mental health distress $[38,49,50]$, and the use of psychoactive substances among MSM $[4,8,11,12]$.

At the highest government levels, between 2002 and 2014, policies and health interventions were developed in Brazil that favoured the MSM. For example, the Committee for LGBT Health at the Ministry of Health, the reassertion of LGBT Rights on to health care at services of the Brazilian National Health System, and the National Policy for LGBT Health $[51,52]$ were developed. However, the country has experienced setbacks in LGBT health policies over the last five years, given the advance of religious groups and conservative social movements in Brazilian society, in Congress, and at the Presidency $[53,54]$. More recently, the current national government, as of 2019, has further exacerbated this situation [54]. The new president and his party - who elected the largest number of members in Congress - were voted on a platform containing explicit rejection of LGBT individuals and identities, publishing a program vowing to exclude LGBT communities from human rights protections and social policies [53]. The Secretary of Continuing Education, Literacy, Diversity and Inclusion, who was responsible for promoting policy to secure sexual, gender, and ethnic diversity in Brazilian public schools, was extinguished. HIV prevention guidelines for transgender population were also removed, arguing that this document contained "content that was offensive to the family" [53].

The current political context in Brazil is one of increased stigma directed towards LGBT communities that most likely will increase DDSO. Between 2009 and 2016, the persistence and increase in DDSO may constitute a significant barrier of access to health services, as well as universal access to antiretroviral therapies to treat and prevent HIV (such as the Pre-and Post-exposure prophylaxis) [55-57].

An unfavourable and stressful environment is increasingly associated with physiological effects that make MSM more vulnerable to a range of diseases [58]. In line with Minority Stress Theory [59, 60], stressors are portrayed as events and conditions requiring constant change, causing exposed individuals to make intense efforts to adapt to new circumstances. Individuals subject to stressors therefore suffer from constant psychological and physical tension, eroding their capacity to adapt and inducing mental and somatic disorders [61]. As Goffman [62] pointed out, the response to the "deviance" embedded in stigma and discrimination can lead to the problematization of previously uncontested terrain: challenges to masculinity and heteronormativity can be seen as a response to serious problems of gender violence and intimate partner violence - both widespread in Brazil and elsewhere. As with in-group stigma, occupying a stigmatized role can offer opportunities for leadership, not just oppression. In light of this, in relation to strategies that diminish DDSO among MSM, there are several initiatives in Latin America including interventions sensitive to gender and culture, focusing on the formation of new values that allow for an expansion of different forms of masculinity [63].

Although this study presents robust results, it also has some limitations. The original questionnaire was not designed to evaluate DDSO. Moreover, we do not have information about the timing or duration of exposure, the context in which the episode occurred, or the intensity and frequency of DDSO. RDS studies furthermore present limitations regarding sample representativeness, potential biases in estimating and sampling social networks and indicator data, and potential violation of several theoretical assumptions of RDS in implementation. Specific analyses using the latest estimators for data collected using this method seek to reduce these biases.

\section{Conclusion}


The study reports a high level of DDSO among MSM in Brazil with notably higher levels among younger MSM. The high prevalence of DDSO reported among white and more educated MSM highlights the "iceberg" nature of DDSO, and that much more discrimination exists than what is being documented. There is certainly a need for more in-depth studies on the association between DDSO, sexual and racial minorities, and the social and political context in which these take place. The rise of patterns of distribution of DDSO demonstrate how contingent stigma and discrimination are on political and moral leadership. In Brazil, monitoring DDSO throws into sharp relief our broad social and political failings.

\section{Declarations}

\section{Ethics approval and consent to participate}

The research project was approved by the Research Ethics Committee of the Federal University of Ceará. ( $\mathrm{n}^{\circ}$ CAAE- 43133915.9.0000.5054 and $n^{\circ}$ 1.024.053). The written consent was obtained for each participant.

\section{Consent for publication}

“Not applicable”

\section{Availability of data and materials}

All data files are available from the Harvard Dataverse:

https://doi.org/10.7910/DVN/CQHEQF

\section{Competing interests}

The authors declare that they have no competing interests.

\section{Funding}

Ministry of Health through the Department of Chronic Disease and Sexuality Transmitted Infections. The funders had no role in study design, data collection and analysis, decision to publish, or preparation of the manuscript.

\section{Authors' contributions}

LM conceptualized, analyzed and interpreted data, and was a major contributor in writing the manuscript the article; ID supervised the fieldwork, analyzed and interpreted data and substantively revised it; AFL supervised the fieldwork, interpreted data and writing the manuscript; DK supervised the fieldwork, interpreted data and writing the manuscript; MDC supervised the fieldwork, analyzed and interpreted data and writing the manuscript;

XPDB reviewed the manuscript; GMR supervised the fieldwork and reviewed substantially the manuscript; MAV supervised the fieldwork and reviewed substantially the manuscript; CK supervised the fieldwork and reviewed substantially the manuscript; AMB supervised the fieldwork and reviewed substantially the manuscript; LK coordinated the research and reviewed substantially the manuscript.

\section{Acknowledgements}


This study was developed with data provided by the Department of Chronic Conditions and Sexually Transmitted Infections of the Health Surveillance Secretariat of the Ministry of Health (Funding). The authors also thank all the respondents and their enthusiastic participation in this troubled time for MSM, without them this study would not be possible.

To the Ministry of Health and to the Department of Chronic Conditions and Sexually Transmitted Infections (DCST). To gays and other MSM who were interviewed. The Brazilian HIV/MSM Surveillance Group: Alexandre Kerr Pontes, Universidade Federal do Rio de Janeiro, Rio de Janeiro; Ana Cláudia Camillo, Fundação Alfredo da Mata, Manaus; Ana Maria de Brito, Ageu Magalhães, Fundação Oswaldo Cruz, Recife; Ana Rita Coimbra MottaCastro, FIOCRUZ/Universidade Federal do Mato Grosso do Sul, Campo Grande; Daniela Riva Knauthe Andréa Fachel Leal, Universidade Federal do Rio Grande do Sul, Porto Alegre; Edgar Merchan-Hermann e Ximena Pamela Diaz, Universidade de Brasília, Brasília; Luana N C Lima, Instituto Evandro Chagas, Belém; Maria Amélia Veras, Faculdade de Ciências Médicas da Santa Casa de São Paulo, São Paulo; Maria Inês Dourado, Universidade Federal da Bahia, Salvador; Lígia Regina Franco SansigoloKerr (lead author: ligiakerr@gmail.com), Universidade

Federal do Ceará, Fortaleza; Lisangela Cristina de Oliveira, Centro Universitário Autônomo do Brasil - UNIBRASIL, Curitiba; Mark Drew Crosland Guimarães, Universidade Federal de Minas Gerais, Belo Horizonte; Raimunda Hermelinda Maia Macena, Universidade Federal do Ceará, Fortaleza; Rosa Salani Mota, Universidade Federal do Ceará, Fortaleza; Maria do Socorro Cavalcante, Secretaria de Saúde do Ceará, Fortaleza; Carl Kendall, Tulane University, New Orleans and Universidade Federal do Ceará, Fortaleza; George Rutherford, University of California San Francisco, San Francisco; Willi McFarland, University of California San Francisco, San Francisco.

\section{References}

1. Frye V, Nandi V, Egan J, Cerda M, Greene E, Tieu H Van, et al. Sexual Orientation- and Race-Based Discrimination and Sexual HIV Risk Behavior Among Urban MSM. 2016;97: 5421-5433. doi:10.1002/jps.21372.Interactions

2. Lancet T. HIV: science and stigma. Lancet. 2014;384: 207. doi:10.1016/S0140-6736(14)61193-4

3. Altman D, Aggleton P, Williams M, Kong T, Reddy V, Harrad D, et al. Men who have sex with men: stigma and discrimination. Lancet. 2012;380: 439-45. doi:10.1016/S0140-6736(12)60920-9

4. Rogers AH, Jardin C, Mayorga NA, Bakhshaie J, Leonard A, Lemaire C, et al. The Relationship of Discrimination Related to Sexual Orientation and HIV-Relevant Risk Behaviors Among Men Who Have Sex with Men. Psychiatry Res. 2018;In Press. doi:10.1016/j.psychres.2018.05.081

5. Aho J, Hakim A, Vuylsteke B, Semde G, Gbais HG, Diarrassouba M, et al. Exploring risk behaviors and vulnerability for HIV among men who have sex with men in Abidjan, Cote d'Ivoire: Poor knowledge, homophobia and sexual violence. PLoS One. 2014;9. doi:10.1371/journal.pone.0099591

6. Sabidó M, Kerr LRFS, Mota RS, Benzaken AS, de A. Pinho A, Guimaraes MDC, et al. Sexual Violence Against Men Who Have Sex with Men in Brazil: A Respondent-Driven Sampling Survey. AIDS Behav. 2015. doi:10.1007/s10461-015-1016-z

7. Ruutel K, Valk A, Lohmus L. Suicidality and Associated Factors Among Men Who Have Sex With Men in Estonia. J Homosex. 2016;64: 1-16. doi:10.1080/00918369.2016.1236578.

8. Vu NTT, Holt M, Phan HTT, La LT, Tran GM, Doan TT, et al. Amphetamine-Type-Stimulants (ATS) Use and Homosexuality-Related Enacted Stigma Are Associated With Depression Among Men Who Have Sex With 
Men (MSM) in Two Major Cities in Vietnam in 2014. Subst Use Misuse. 2017;52: 1411-1419.

doi:10.1080/10826084.2017.1284233

9. Hylton E, Wirtz AL, Zelaya CE, Latkin C, Peryshkina A, Mogilnyi V, et al. Sexual Identity, Stigma, and Depression: the Role of the "Anti-gay Propaganda Law" in Mental Health among Men Who Have Sex with Men in Moscow, Russia. J Urban Heal. 2017;94: 319-329. doi:10.1007/s11524-017-0133-6

10. Liu Y, Jiang C, Li S, Gu Y, Zhou Y, An X, et al. Association of recent gay-related stressful events with depressive symptoms in Chinese men who have sex with men. 2018; 1-7.

11. De Boni RB, Machado IK, De Vasconcellos MTL, Hoagland B, Kallas EG, Madruga JV, et al. Syndemics among individuals enrolled in the PrEP Brasil Study. Drug Alcohol Depend. 2018;185: 168-172. doi:10.1016/j.drugalcdep.2017.12.016

12. Folch C, Esteve A, Zaragoza K, Muñoz R, Casabona J. Correlates of intensive alcohol and drug use in men who have sex with men in Catalonia, Spain. Eur J Public Health. 2010;20: 139-145. doi:10.1093/eurpub/ckp091

13. Cerqueira-Santos E, Calvetti PU, Rocha KB, Moura A, Barbosa LH, Hermel J. Percepção de Usuários Gays, Lésbicas, Bissexuais e Transgêneros, Transexuais e Travestis do Sistema Único de Saúde. R Interam Psicol. 2010;44: 235-245.

14. Araújo MAL, Montagner MA, da Silva RM, Lopes FL, de Freitas MM. Symbolic violence experienced by men who have sex with men in the primary health service in Fortaleza, Ceará, Brazil: negotiating identity under stigma. AIDS Patient Care STDS. 2009;23: 663-668. doi:10.1089/apc.2008.0123

15. Risher K, Adams D, Sithole B, Ketende S, Kennedy C, Mnisi Z, et al. Sexual stigma and discrimination as barriers to seeking appropriate healthcare among men who have sex with men in Swaziland. J Int AIDS Soc. 2013;16: 1-9. doi:10.7448/ias.16.3.18715

16. Ayala G, Santos G. Short report Will the global HIV response fail gay and bisexual men and other men who have sex with men? J Int AIDS Soc. 2016;21098: 1-5.

17. Logie CH, Lacombe-duncan A, Brien N, Jones N, Lee-foon N, Levermore $K$, et al. Barriers and facilitators to HIV testing among young men who have sex with men and transgender women in Kingston , Jamaica: a qualitative study. J Int AIDS Soc. 2017;20: 1-8. doi:10.7448/IAS.20.1.21385

18. Stojisavljevic S, Djikanovic B, Matejic B. 'The Devil has entered you': A qualitative study of Men Who Have Sex With Men (MSM) and the stigma and discrimination they experience from healthcare professionals and the general community in Bosnia and Herzegovina. PLoS One. 2017;12: 1-17. doi:10.1371/journal. pone.0179101

19. Lucas. State-sponsored homophobia 2019. Geneva; 2019. Available: https://ilga.org/state-sponsoredhomophobia-report

20. I LM, li ID, Augusto L, Silva V, Iv SB, V AMDB. Factors associated with self-reported discrimination against men who have sex with men in Brazil. 2017; 1-11.

21. Magno L, Silva LAV da, Guimarães MDC, Veras MA de SM, Deus LFA de, Leal AF, et al. Discrimination based on sexual orientation against MSM in Brazil: a latent class analysis. Rev Bras Epidemiol. 2019;22: 1-15. doi:10.1590/1980-549720190003.supl.1

22. Mizuno Y, Borkowf C, Millett G a., Bingham T, Ayala G, Stueve A. Homophobia and racism experienced by latino men Who have sex with men in the United States: Correlates of exposure and associations with hiv risk behaviors. AIDS Behav. 2012;16: 724-735. doi:10.1007/s10461-011-9967-1 
23. De Boni R, Veloso VG, Grinsztejn B. Epidemiology of HIV in Latin America and the Caribbean. Curr Opin HIV AIDS. 2014;9: 192-8. doi:10.1097/COH.0000000000000031

24. Malta M, Beyrer C. The HIV epidemic and human rights violations in Brazil. J Int AIDS Soc. 2013;16: 10-12. doi:10.7448/IAS.16.1.18817

25. Parker RG. Behaviour in Latin American men: implications for HIV/AIDS interventions. Int J STD AIDS. 1996;7 Suppl 2: 62-65. doi:10.1258/0956462961917663

26. Faria F. Casamento gay não é lei, mas é direito garantido pela Justiça; entenda. Folha de São Paulo. 5 Nov 2018.

27. Coletta R Della. O STF conclui julgamento e enquadra homofobia na lei dos crimes de racismo. Folha de São Paulo. 13 Jun 2019. Available: https://www1.folha.uol.com.br/cotidiano/2019/06/stf-concluijulgamento-e-enquadra-homofobia-na-lei-dos-crimes-de-racismo.shtml

28. Michels E, Mott L, Paulinho. Mortes Violentas de LGBT+ No Brasil: Relatório 2018. Salvador-BA; 2018. Available: https://homofobiamata.files.wordpress.com/2019/01/relatorio-2018-1.pdf

29. Magno L, Dourado I, Silva LAV da, Brignol S, Brito AM De, Guimarães MDC, et al. Factors associated with self-reported discrimination against men who have sex with men in Brazil. Rev Saude Publica. 2017;51: 111.

30. Kendall C, Kerr L, Mota RS, Guimarães MDC, Leal AF, Merchan-Hamann E, et al. The 12 city HIV Surveillance Survey among MSM in Brazil 2016 using respondent-driven sampling: a description of methods and RDS diagnostics. Rev Bras Epidemiol. 2019;22: 1-17. doi:10.1590/1980-549720190004

31. Heckathorn D. Respondent-driven sampling: a new approach to the study of hidden populations. Soc Probl. 1997.

32. Collins LM, Lanza ST. Latent Class and Latent Transition Analysis: With Applications in the Social, Behavioral, and Health Sciences. 2010. doi:10.1002/9780470567333

33. ABEP AB de E de P. Critério Brasil 2015 e atualização da distribuição de classes para 2016. Critério de Classificação Econômica Brasil. 2015: 6. Available: http://www.abep.org/criterio-brasil

34. Gile KJ, Handcock MS. 7. Respondent-Driven Sampling: An Assessment of Current Methodology. Sociol Methodol. 2010;40: 285-327. doi:10.1111/j.1467-9531.2010.01223.x

35. Handcock MS, Fellows IE, Gile KJ. RDS Analyst: Software for the Analysis of Respondent-Driven Sampling Data, Version 0.42,. 2014. Available: http://hpmrg.org

36. Abreu MNS, Siqueira AL, Caiaffa WT. Ordinal logistic regression in epidemiological studies. Rev Saude Publica. 2009;43: 183-194.

37. Santos G-M-. M, Beck J, Wilson P a, Hebert P, Makofane K, Pyun T, et al. Homophobia as a barrier to HIV prevention service access for young men who have sex with men. JAIDS J Acquir Immune Defic Syndr. 2013;63: e167-e170.

38. Huebner DM, Rebchook GM, Kegeles SM. Experiences of harassment, discrimination, and physical violence among young gay and bisexual men. Am J Public Health. 2004;94: 1200-3. Available:

http://www.pubmedcentral.nih.gov/articlerender.fcgi?artid=1448421\&tool=pmcentrez\&rendertype=abstract

39. Nuttbrock L, Hwahng S, Bockting W, Rosenblum A, Mason M, Macri M, et al. Psychiatric impact of genderrelated abuse across the life course of male-to-female transgender persons. J Sex Res. 2010;47: 12-23. doi:10.1080/00224490903062258 
40. IGBE. Pretos ou pardos estão mais escolarizados, mas desigualdade em relação aos brancos permanece. 2019. Available: https://agenciadenoticias.ibge.gov.br/agencia-sala-de-imprensa/2013-agencia-denoticias/releases/25989-pretos-ou-pardos-estao-mais-escolarizados-mas-desigualdade-em-relacao-aosbrancos-permanece

41. Magno L, Sousa S De. Organização dos Organização dos serviços serviços de Redes de Atenção à Saúde Fatos históricos Normas Operacionais do SUS Fatos históricos Normas Operacionais do SUS Fatos históricos Normas Operacionais do SUS Pactos Pactos. 2017;5: 1-9.

42. Reisen CA, Brooks KD, Zea MC, Poppen PJ, Bianchi FT. Can additive measures add to an intersectional understanding? Experiences of gay and ethnic discrimination among HIV-positive Latino gay men. Cult Divers Ethn Minor Psychol. 2013;19: 208-217. doi:10.1037/a0031906

43. Thai M. Sexual Racism Is Associated with Lower Self-Esteem and Life Satisfaction in Men Who Have Sex with Men. Arch Sex Behav. 2019. doi:10.1007/s10508-019-1456-z

44. Watkins-Hayes C. Intersectionality and the Sociology of HIV/AIDS: Past, Present, and Future Research Directions. Annu Rev Sociol. 2014;40: 431-457. doi:10.1146/annurev-soc-071312-145621

45. Newcomb ME, Mustanski B. Clinical Psychology Review Internalized homophobia and internalizing mental health problems: A meta-analytic review. Clin Psychol Rev. 2010;30: 1019-1029. doi:10.1016/j.cpr.2010.07.003

46. Berghe W Vanden, Dewaele A, Vincke NC and J. Minority-Specific Determinants of Mental Well-Being Among Lesbian, Gay, and Bisexual Youth. J Appl Soc Psychol. 2010;40: 153-166.

47. Meyer IH. Minority Stress and Mental Health in Gay Men. J Health Soc Behav. 1995;36: 38. doi: $10.2307 / 2137286$

48. Strömdahl S, Williams AO, Eziefule B, Emmanuel G, Iwuagwu S, Anene O, et al. An assessment of stigma and human right violations among men who have sex with men in Abuja, Nigeria. BMC Int Health Hum Rights. 2019;19: 1-7. doi:10.1186/s12914-019-0190-x

49. Hatzenbuehler ML, Nolen-Hoeksema S, Erickson SJ. Minority stress predictors of HIV risk behavior, substance use, and depressive symptoms: results from a prospective study of bereaved gay men. Health Psychol. 2008;27: 455-462. doi:10.1037/0278-6133.27.4.455

50. Anderson AM, Ross MW, Nyoni JE, McCurdy S a. High prevalence of stigma-related abuse among a sample of men who have sex with men in Tanzania: implications for HIV prevention. AIDS Care. 2015;27: 63-70. doi:10.1080/09540121.2014.951597

51. Brasil. Política nacional de saúde integral de lésbicas, gays, bissexuais, travestis e transexuais - LGBT. Brasília, DF: Ministério da Saúde; 2013.

52. Brasil. Carta dos direitos dos usuários da saúde llustrada. Brasília Ministério da Saúde. 2006; 1-12. Available: http://scholar.google.com/scholar?hl=en\&btnG=Search\&q=intitle:Carta+dos+direitos+dos+usu?+rios+da+sa?de\#1

53. Brandão ER, Cabral S, Brandão ER. Sexual and reproductive rights under attack: the advance of political and moral conservatism in Brazil Sexual and reproductive rights under attack: the advance of political and moral conservatism in Brazil. Sex Reprod Heal Matters. 2019;27: 1-11. doi:10.1080/26410397.2019.1669338

54. Montenegro L, Velasque L, LeGrand S, Whetten K, de Mattos Russo Rafael R, Malta M. Public Health, HIV Care and Prevention, Human Rights and Democracy at a Crossroad in Brazil. AIDS Behav. 2020;24: 1-4. doi:10.1007/s10461-019-02470-3

Page $21 / 22$ 
55. Khan S. Examining HIV/AIDS-Related Stigma at Play: Power, Structure, and Implications for HIV Interventions. Health Commun. 2019;0: 1-11. doi:10.1080/10410236.2019.1652386

56. Ferraz D, Couto MT, Zucchi EM, Calazans GJ, dos Santos LA, Mathias A, et al. AIDS- and sexuality-related stigmas underlying the use of post-exposure prophylaxis for HIV in Brazil: findings from a multicentric study. Sex Reprod Heal Matters. 2019;27. doi:10.1080/26410397.2019.1650587

57. Magno L, Dourado I, Sutten Coats C, Wilhite D, da Silva LA V., Oni-Orisan O, et al. Knowledge and willingness to use pre-exposure prophylaxis among men who have sex with men in Northeastern Brazil. Glob Public Health. 2019;0: 1-14. doi:10.1080/17441692.2019.1571090

58. Li MJ, Takada S, Okafor CN, Gorbach PM, Shoptaw SJ, Cole SW. Experienced homophobia and gene expression alterations in Black and Latino men who have sex with men in Los Angeles County. Brain Behav Immun. 2019; 0-1. doi:10.1016/j.bbi.2019.09.021

59. Meyer IH. Minority stress and mental health in gay men. J Health Soc Behav. 1995;36: 38-56. doi:10.2307/2137286

60. Meyer IH. Prejudice, Social Stress, and Mental Health in Lesbian, Gay, and Bisexual Populations: Conceptual Issues and Research Evidence. Psychol Bull. 2003;129: 674-697. doi:10.1002/nbm.3066.Non-invasive

61. Meyer IH. Prejudice, Social Stress, and Mental Health in Lesbian, Gay, and Bisexual Populations: Conceptual Issues and Research Evidence. Psychol Bull. 2003;129: 674-697. doi:10.1037/0033-2909.129.5.674

62. Goffman E. Estigma: notas sobre a manipulação da identidade manipulada. $4^{\circ}$ ed. Rio de Janeiro: LTC; 2013.

63. Martinez O, Wu E, Levine EC, Muñoz-Laboy M, Fernandez MI, Bass SB, et al. Integration of social, cultural, and biomedical strategies into an existing couple-based behavioral HIV/STI prevention intervention: Voices of latino male couples. PLoS One. 2016;11: 1-22. doi:10.1371/journal.pone.0152361 